\title{
Contaminant impact on interactions of molecular probes with lysosomes in living hepatocytes from dab Limanda limanda
}

\author{
D. M. Lowe, M. N. Moore, B. M. Evans \\ Plymouth Marine Laboratory, Citadel Hill, Plymouth, Devon PL1 2PB, United Kingdom
}

\begin{abstract}
During the Bremerhaven Workshop, effects of contaminants along a well characterised North Sea contaminant gradient heading northwest of the port of Bremerhaven in the German Bight were determined in dab Limanda limanda using in vitro techniques on isolated hepatocytes. Results demonstrated that lysosomal membrane integrity was impaired following contaminant exposure which resulted in an inability to retain the supravital dye neutral red and in reduced lysosomal uptake of the fluorescent probe acridine orange. There was an improvement in the condition of exposed hepatocytes in samples taken further offshore, and away from the source of the contaminant; however, this trend was reversed in samples taken from the furthermost station on the northeast tail of the Dogger Bank These findings are related to the histopathological evidence of abnormal lysosomal enlargement and disturbance of liver cell structure.
\end{abstract}

\section{INTRODUCTION}

When considering the effects of contaminants on intact cells for biological impact assessment studies, the methods frequently chosen to measure effects in marine fish species are gross pathology and histopathology. Whilst recognising the contribution made by these 2 disciplines, toxicologists and pharmacologists study. ing the effects of drugs and compounds on cells and tissues make additional use of in vitro assays. In support of the use of cell lines for the analysis of toxicity, Grisham \& Smith (1984) argued that as the 'actions of chemicals that produce disease and death in animals are ultimately exerted at the cellular level; the goal of in vitro toxicology was to use systems of cultured cells as simple and manipulatable analogs of animals'. In addition, the use of in vitro assays for the detection of effects of toxic substances has the advantage, over histopathological techniques for example, that followon exposures can be undertaken using different compounds on the same group of cells thereby reducing the number of animals sacrificed and eliminating the consequences of genetic heterogeneity between samples and studies
Studies in recent years (Babich \& Borenfreund 1987 a b, c, 1988a, b) have demonstrated, using a neutral red (CI No 50040) assay (Finter 1969, Borenfreund \& Puerner 1985), the applicability of in vitro assays for the demonstration of contaminant-induced damage in different cell types of fish under experimental conditions. The neutral red assay, as a measure of cell damage, makes use of the fact that only lysosomes in healthy cells take up and retain the supravital dye. In essence the technique, as developed for experimental toxicological studies, involves incubating cells in a test substance, followed by a second incubation for $3 \mathrm{~h}$ in neutral red solution. The cells are then washed briefly in a formalin solution and then the dye extracted in a $1 \%$ acetone-50\% ethanol solution and measured spectrophotometrically; the amount of dye retained within the cell provides a measure of the degree of membrane damage.

Another cationic probe, acridine orange $(\mathrm{Cl}$ No 26115), is also taken up by living cells and sequestered in lysosomes where it can be detected fluorescently using blue light excitation (Allison \& Young 1969).

There is much evidence for damage to lysosomes by enviromental xenobiotics in aquatic organisms (Moore 
1985, 1990, Hinton 1989, Köhler 1989, 1990). However, this evidence has all been obtained from tissue sections rather than living cells. The aim of the present investigation was to extend the study of xenobioticinduced lysosomal injury to the realm of living cells isolated from the livers of fish caught in 'clean' and contaminated sites.

The workshop gave an opportunity to test the suitability of in vitro assays for use as field monitoring tools using isolated hepatocytes and ultimately to compare the findings with those obtained from gross pathological and histopathological investigations of fish from the same sampling stations.

\section{MATERIALS AND METHODS}

Samples and sampling. Samples of the flatfish dab Limanda limanda were collected from Stns 3, 5, 6, 7 \& 9 along a pollution gradient in the North Sea due northwest from the mouth of the Rivers Weser and Elbe in the German Bight. On receipt on deck the fish were sexed, measured and placed in flow-through tanks for transportation back to the laboratory. The total length of the sample transect was of the order of $200 \mathrm{~km}$, so to reduce any adverse effect due to motion stress, the fish were not removed from the tanks for a period of $6 \mathrm{~h}$ on arrival at the laboratory.

Disaggregation protocol. A random sample of 10 non-visibly diseased females, size range 17 to $25 \mathrm{~cm}$, was taken for each station, and the livers excised. Approximately half of each liver was then sliced into small pieces $(<2 \mathrm{~mm}$ cubes), placed in a Trypsinising flask (Belco) containing $50 \mathrm{ml}$ of Earles $\mathrm{Ca}^{2}+\mathrm{Mg}^{2+}$ free balanced salt solution (ICN Flow), to which had been added $5 \mathrm{mM}$ EDTA and $0.5 \% \mathrm{NaCl}$, and incubated for $30 \mathrm{~min}$ with continuous agitation. The divalent cations $\mathrm{Ca}^{2+}$ and $\mathrm{Mg}^{2+}$ are thought to be involved in intercellular attachments; their absence from the incubation medium results in competition for these ions and their ultimate removal from the intercellular plaque thereby facilitates the disaggregation procedure (Baksi \& Frazier 1990). Similarly the inclusion of the chelating agent EDTA in the incubation medium loosens intercellular binding sites by removing the $\mathrm{Ca}^{2+}$ and $\mathrm{Mg}^{2+}$ from the intercellular plaque. The primary incubation also served to remove the majority of blood cells that would otherwise contaminate the hepatocyte preparation. The whole process of disaggregation, including centrifugation, was carried out at $10^{\circ} \mathrm{C}$ and all solutions used were sterile. The contents of the flask were then poured over $280 \mu \mathrm{m}$ mesh silk, the filtrate discarded and the retained solid material placed back into the flask plus $30 \mathrm{ml}$ of Hanks balanced salt solution (ICN Flow) to which had been added $30 \mathrm{mg} \mathrm{NaCl}$,
$51.0 \mathrm{mg} \mathrm{NaHCO} 3,282 \mathrm{mg}$ HEPES, $0.024 \mathrm{ml} 1 \mathrm{~N} \mathrm{HCl}$, $5 \mathrm{mg}$ collagenase (Sigma Type 1V) and $5 \mathrm{mg}$ lipase. The addition of lipase was found to be necessary for the disaggregation of dab livers only; both plaice Pleuronectes platessa and flounder Platichthys flesus livers disaggregated effectively with collagenase alone (Lowe unpubl.). The tissues were incubated in the enzyme solution for $40 \mathrm{~min}$, with continuous agitation, and the resulting cell suspension poured through $280 \mu \mathrm{m}$ mesh silk into $30 \mathrm{ml}$ siliconised centrifuge tubes and the cells spun down at $1000 \mathrm{rpm}(200 \times \mathrm{g})$ for 2 min. In order to wash the cells the supernatant was decanted off and the cells resuspended in the same balanced salt solution, but without the additition of the digestive enzymes, and centrifuged as before. This washing procedure was repeated 3 times. Following the final wash the cells were resuspended in $30 \mathrm{ml}$ of an amended Eagles Minimum Essential Medium (ICN Flow) (containing additionally $50 \mathrm{ml}$ Foetal Bovine Serum, $10 \mathrm{ml}$ of non-essential amino acids and $10 \mathrm{ml}$ of $200 \mathrm{mM} \mathrm{L}$-glutamine $\mathrm{l}^{-1}$ ) and stored at $10^{\circ} \mathrm{C}$.

Neutral red retention assay. Previous use of the dye neutral red in membrane damage studies has involved exposing cells to a test contaminant and then incubating them in a neutral red solution. In a field situation the tissues have already been exposed to a contaminant and therefore the cells only require to be dyeloaded. Neutral red (10 mg) was dissolved in $100 \mathrm{ml}$ of the above sterile amended culture medium and filtered through a $0.2 \mu \mathrm{m}$ cartridge filter attached to a hypodermic syringe; both the cartridge and syringe were purchased sterile packed. The neutral red solution $(40 \mu \mathrm{l})$ was then added to a single sample of cell suspension $(40 \mu \mathrm{l})$ on a microscope slide and a $22 \times 22 \mathrm{~mm}$ coverslip applied; this gives a final dye concentration of $<50 \mu \mathrm{g} \mathrm{ml}^{-1}$ for the incubation. The slides were placed in a humidity chamber at room temperature and then systematically removed and examined under a microscope at 15, 30 and thereafter 30 min intervals for evidence of the loss of dye from the lysosomal compartment into the cytosol and the time recorded for this process to occur for each individual. The experiment was terminated at $180 \mathrm{~min}$ (see below). In developing this procedure it was found that the dye was taken up almost immediately into the lysosomal compartment of the hepatocytes of healthy fish in uncontaminated medium and that the rest of the cytoplasm remained colourless for up to $180 \mathrm{~min}$ at which point the experiment was terminated. By contrast, in hepatocytes incubated in vitro with the model hydrocarbon fluoranthene, the dye was observed to immediately enter and be distributed throughout the cytoplasm and lysosomes indicating severe membrane damage (Lowe unpubl.). Differences between stations were examined by a Kruskal-Wallis 1-way analysis of variance fol- 
lowed by multiple comparison tests on specific pairs of means (Mann-Whitney).

Acridine orange assay. Aliquots $(20 \mu \mathrm{l})$ of the liver cell suspension were placed on microscope slides and the hepatocytes were allowed to attach for $15 \mathrm{~min}$ in a humidity chamber at $20^{\circ} \mathrm{C}$. Acridine orange $(2 \mu \mathrm{l}$ at a concentration of $1 \mu \mathrm{g} \mathrm{ml} \mathrm{m}^{-1}$ in HBSS diluted from a stock solution in DMSO) was added and the cells were examined under FITC epifluorescence after a further $30 \mathrm{~min}$ at $20^{\circ} \mathrm{C}$. Cell images (>100 cells sample ${ }^{-1}$ ) were captured on high resolution video tape (Sony Pro $\mathrm{X}$ ) using a Sony Colour Video Camera coupled to a Zeiss Axiomat fluorescence microscope. A random subset of 20 images of cells were scored against a set of prepared micrographs of lysosomal fluorescence for acridine orange (grey level range 0 to 250); the fluorescent cells on the prepared micrographs having been previously calibrated with a Molecular Dynamics Sarastro Confocal Laser Scanning Microscope interfaced to a Silicon Graphics computer.

\section{RESULTS}

The disaggregation protocol developed for this study gave typically a cell viability in excess of $95 \%$ using eosin $Y$ exclusion as an indicator of cell fitness and a yield in the order of $2 \times 10^{6}$ cells $\mathrm{ml}^{-1}$.

Lohse (1990) identified Stn 3 of the transect used for these studies as the most contaminated site with levels of contaminants (organochlorines, petroleum hydrocarbons, metals) decreasing through Stns 5 \& 6 with Stn 7 as the least contaminated; at Stn 9 levels increased once again. Lipophilic organic compounds are the major contaminants at the inshore stations whereas at Stn 9 on the Dogger Bank metal contaminants are more important.

The neutral red retention assay (Figs. 1 \& $2 a$, b) indicated that the shortest dye retention times were in cells from Stns $3 \& 5$, which were not significantly different from each other but were significantly less than all other stations ( $p<0.002)$. Hepatocytes from Stns $6 \& 9$ had retention times that were significantly less than Stn 7 ( $p<0.001$ and $p<0.002$ respectively).

Lysosomal uptake of acridine orange showed that there was essentially a zero uptake of the probe by lysosomes in Stn 3 hepatocytes, with increasing uptake in other stations from 5 to 7 and a similar uptake in Stn $7 \& 9$ (Figs. 2c, d \& 3). Assessment of the lysosomal uptake of the probe was based on the orange-red fluorescence characteristic of lysosomal retention of the dye. Some cells in the samples from Stn 3 showed a pale green lysosomal fluorescence similar to that of the DNA in live cells.

Correlation analysis of the neutral red retention and

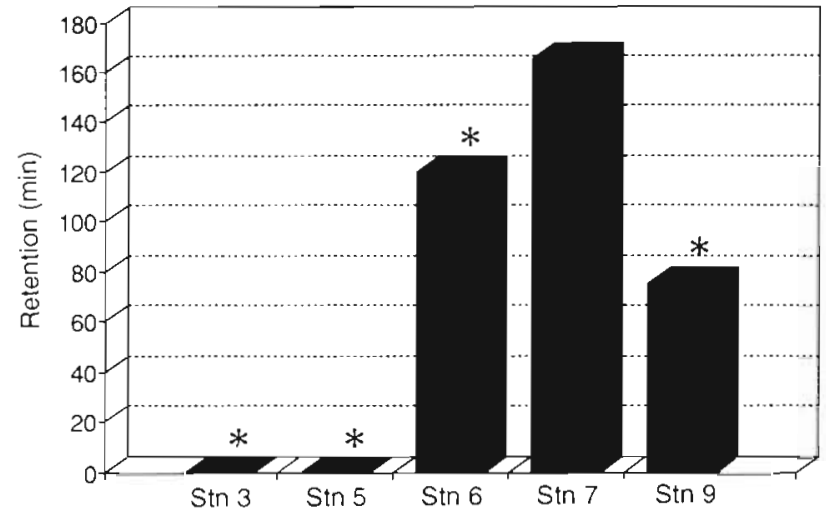

Fig. 1. Limanda limanda. Median values of lysosomal neutral red retention times in hepatocytes from the transect sample sites. ('Significance level: see 'Results', $n=10$ )

acridine orange fluorescence data indicated a significant inverse relationship between liver PCB (total congeners measured; Cofino et al. 1992) and acridine orange fluoresence $(r=-0.88, p>0.05, \mathrm{df}=3)$. The 2 lysosomal parameters themselves showed a significant correlation (Spearman Rank Corr. Coeff. $=0.64$, $\mathrm{p}<0.00005, \mathrm{n}=50$ ).

The in vitro assays indicated that contaminant exposure resulted in damage to the lysosomal system. Evidence of cell damage was supported by stereological analysis of hepatocyte vacuolation of liver tissues involving enlarged lysosomes, which indicated that a significant increase had occurred compared to all other sites (Fig. 2e, f). In some instances the vacuoles, which in frozen sections were observed to be full of lipid, occupied more than $80 \%$ of the projected area of the cell. In addition the norma] tubular architecture of the liver tissue was difficult to discern.

\section{DISCUSSION}

Acridine orange, like neutral red, is lipophilic and as such will freely permeate the cell membrane (LüllmanRauch 1979). However, within the lysosomes both compounds become trapped by protonization and can be visualised microscopically. The degree of trapping of these lysosomotropic molecular probes depends on the $\mathrm{pH}$ of the lysosome as well as the efficiency of its membrane associated proton pump (Seglen 1983), so any impairment of this latter system will result in a reduction of the dye retention. Acridine orange is also believed to bind to polyanionic sites associated with the matrix glycoproteins within the lysosome (Koenig 1969). This particular probe fluoresceses orange-red at high concentrations and green at low concentrations as was observed in the hepatocyte lysosomes at Stn 3.

The objective of this study was to evaluate in vitro 
a

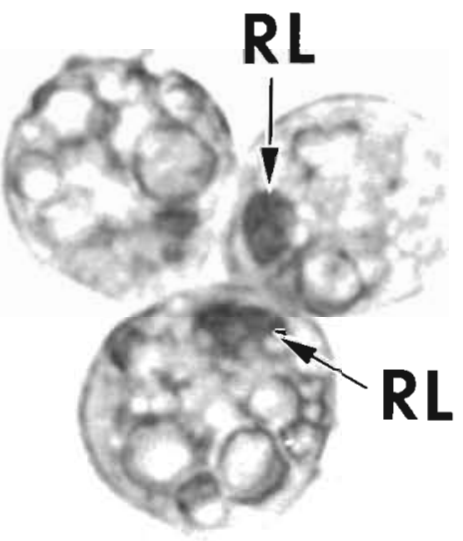

1
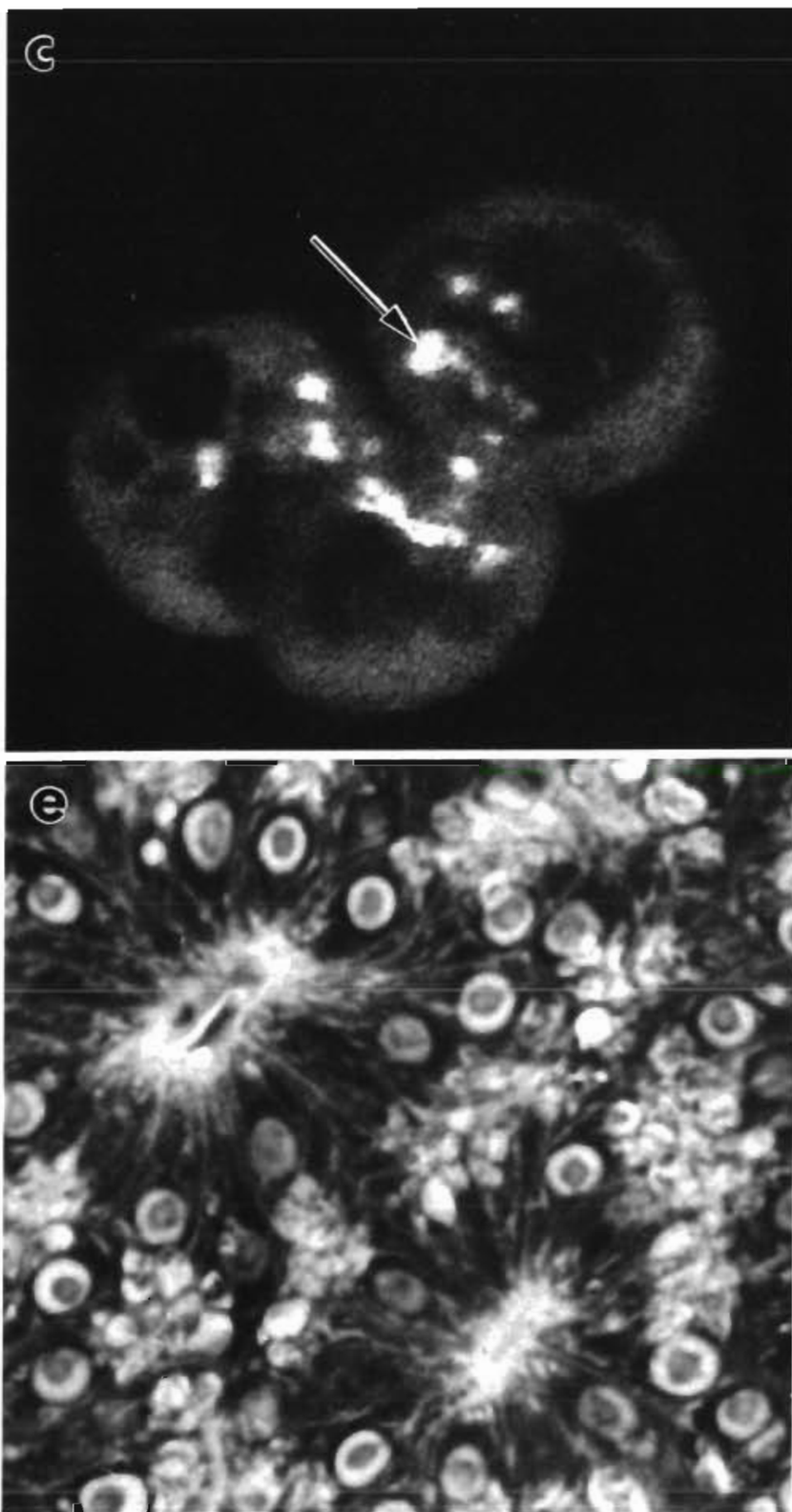

b
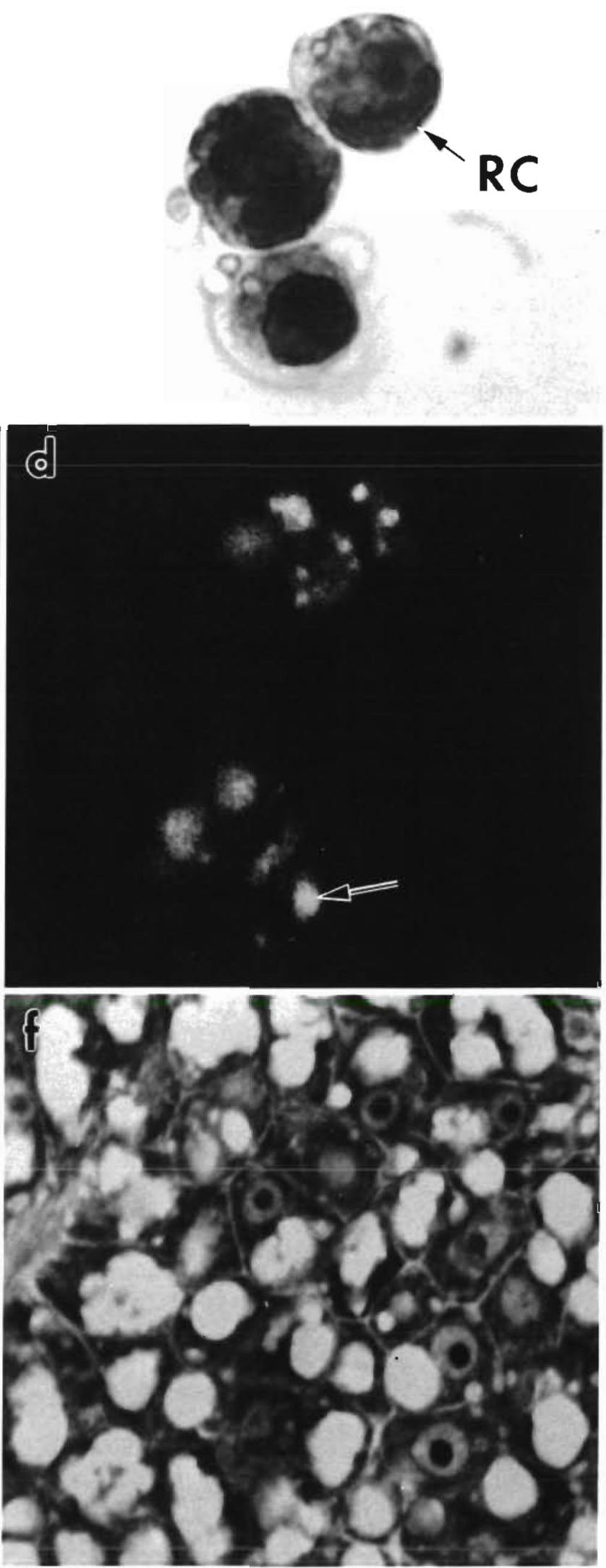
Fig. 2. Limanda limanda. (a) Isolated hepatocytes showing neutral red retained within the lysosomes (RL); $\times 1900$. (b) Isolated hepatocytes showing neutral red diffused throughout cytoplasm $(\mathrm{RC}) ; \times 1900$. (c) Isolated hepatocyte showing normal fluorescence (red-orange) of the lysosomes following uptake of acridine orange, arrowed; $\times 2800$. (d) Isolated hepatocyte showing impaired uptake of acridine orange, arrowed (fluoresces pale green); $\times 2800$. (e) Methacrylate section $(3 \mu \mathrm{m})$ of dab liver from Stn 7 showing normal tubular architecture. (f) Methacrylate section $(3 \mu \mathrm{m})$ of dab liver from Stn 3 showing highly vacuolated appearance and loss of tubular architecture

techniques for use in biological impact assessment studies along a known contaminant gradient in the North Sea. The results of the neutral red retention (NRR) and the acridine orange assays follow the trend of the published contaminant levels (Lohse 1990, Cofino et al. 1992) along the transect and indicate that lysosomal membrane damage had occurred. The NRR technique failed to detect any difference in lysosomal membrane damage between Stns 3 \& 5; however, the contaminant gradient is known not to be linear and it may be that the toxic thresholds (Warren 1971) of the individual components of the contaminant 'cocktail' were exceeded at both sites. The indication of cell damage shown by the in vitro assay is supported by the histopathological test results which indicate that major cell and tissue changes were occurring that are indicative of metabolic failure and enhanced tissue maintenance and repair in fish at Stn 3.

Lysosomal injury, induced by chemical contaminants, has been reported in a number of teleost fish (Hinton 1989, Köhler 1989, 1990, 1991). The present study confirms that lysosomes are indeed a target for the toxic action of xenobiotics and extends the evidence to living cells. The results obtained with both the cationic probes are very similar thus lending support to the proposed mechanism of lysosomal damage, namely, perturbation of the membrane structure and

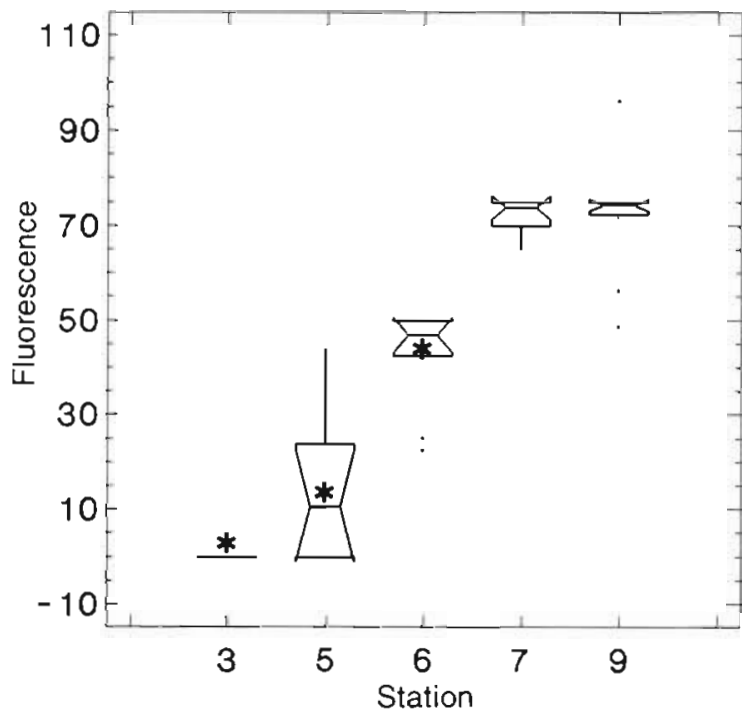

Fig. 3. Limanda limanda. Notched-box and whisker plot showing acridine orange uptake in hepatocyte lysosomes from transect sample sites. ( $p<0.05, n=10$, Mann-Whitney) associated impairment of the ATP-dependent proton pump.

Acknowledgements. Funded under contract to the UK Department of the Environment as part of its coordinated programme of research on the North Sea (PECD Ref.7/8/137). Assistance in the preparation of isolated hepatocytes by Barry Evans is gratefully acknowledged. I would also like to express my thanks to Zeiss Oberkochen (Hamburg) for their generous loan of an Axiomat fluourescence microscope and TV camera.

\section{LITERATURE CITED}

Allison, A. C., Young, M. R. (1969). Vital staining and fluorescence microscopy of lysosomes. In: Dingle, J. T., Foli, H. B. (eds.) Lysosomes in biology and pathology, Vol. 2. Elsevier, Amsterdam, New York, p. 600-628

Babich, H., Borenfreund, E. (1987a). Structure-activity relationship (SAR) models established in vitro with neutral red cytotoxicity assay. Toxic. in Vitro 1(1): 3-9

Babich, H., Borenfreund, E. (1987b). Fathead minnow FHW cells for use in in vitro cytotoxicity assays of aquatic pollutants. Ecotox. Environment Safety 14: 78-87

Babich, H., Borenfreund, E. (1987c). Polycyclic aromatic hydrocarbon in vitro cytotoxicity to Bluegill BF-2 cells: mediation by $\mathrm{S}-9$ microsomal fraction and temperature. Toxicol. Lett. 36: 107-116

Babich, H., Borenfreund, E. (1988a). In Vitro cytotoxicity of polychlorinated biphenyls (PCBs) and toluenes to cultured Bluegill Sunfish BF-2 cells. In: Adams, W. J., Chapman, G. A., Landis, W. G. (eds.) Aquatic toxicology and hazard assessment, Vol. 10, ASTM STP 971. Am. Soc. Testing and Materials, Philadelphia, p. 454-462

Babich, H., Borenfreund, E. (1988b). Structure-activity relationships for diorganotins, chlorinated benzenes and chlorinated anilines established in Bluegill Sunfish BF-2 cells. Fundam. appl. Toxicol. 10: 295-301

Baksi, S. M., Frazier, J. M. (1990). Isolated fish hepatocytes model systems for toxicology research. Aquat. Toxicol. 16: 229-256

Borenfreund, E., Puerner, J. A. (1985). Toxicity determined in vitro by morphological alterations and neutral red absorption. Toxicol. Lett. 24: 119-124

Cofino, W. P., Smedes, F., de Jong, S. A., Abarnou, A., Boon, J. P., Davies, I. M., Klungsøyr, J., Wilhelmsen, S., Law, R. J., Whinnett, J. A., Schmidt, D., Wilson, S. (1992). The chemistry programme. Mar. Ecol. Prog. Ser. 91: 47-56

Finter, N. B. (1969). Dye uptake methods for assessing viral cytopathogenicity and their application to interferon assays. J. gen. Virol. 5: 419-427

Grisham, J. W., Smith, G. J. (1984). Predictive and mechanistic evaluation of toxic responses in mammalian cell culture systems. Pharmacol. Rev. 36: 151-169

Hinton, D. E. (1989). Environmental contamination and cancer in fish. Mar. environ. Res. 28: 411-416

Koenig, H. (1969). Lysosomes in the nervous system. In: 
Dingle, J. T., Fell, H. B. (eds.) Lysosomes in biology and pathology, Vol. 2. Elsevier, Amsterdam, New York, p. $111-161$

Köhler, A. (1989). Regeneration of contaminated-induced liver lesions in flounder - experimental studies towards the identification of cause effect relationships. Aquat. Toxicol. 14: 203-232

Köhler, A. (1990). Identification of contaminant-induced cellular and subcellular lesions in the liver of flounder (Platichthys flesus L.) caught at differently polluted sites. Aquat. Toxicol. 16: 271-294

Köhler, A. (1991). Lysosomal perturbations in fish liver as indicators for toxic effects of environmental pollution. Comp. Biochem. Physiol. 100C: 123-127

Lohse, J. (1990). Distribution of organochlorine pollutants in North Sea sediments. In: Kruize, P. R. (ed.) North Sea pollution - technical strategies for improvement. Wat. Sci. Tech. 24: 107-113

Lüllman-Rauch, R. (1979). Drug-induced lysosomal storage disorders. In: Dingle, J. T., Jacques, P. J., Shaw, H. I. (eds.) Lysosomes in biology and pathology, Vol. 6. Elsevier, Amsterdam, New York, p. 49-129

Moore, M. N. (1985). Cellular responses to pollutants. Mar. Pollut. Bull. 16: 134-139

Moore, M. N. (1990). Lysosomal cytochemistry in marine environmental monitoring. Histochem. J. 22: 187-191

Seglen, P. O. (1983). Inhibitors of lysosomal function. Methods Enzymol. 96: 737-765

Warren, C. E. (1971). Biology and water pollution control. Saunders \& Co., Philadelphia 